NBER WORKING PAPER SERIES

\title{
HAPPINESS AND THE HUMAN DEVELOPMENT INDEX: AUSTRALIA IS NOT A PARADOX
}

\author{
Andrew Leigh \\ Justin Wolfers \\ Working Paper 11925 \\ http://www.nber.org/papers/w11925
}

\author{
NATIONAL BUREAU OF ECONOMIC RESEARCH \\ 1050 Massachusetts Avenue \\ Cambridge, MA 02138 \\ January 2006
}

We are grateful to Andrew Norton for supplying us with happiness data for Australia in several recent years, and to David Blanchflower, Nick Carroll, Richard Easterlin, Paul Frijters, Andrew Norton, Andrew Oswald, Betsey Stevenson, Brandon Verblow and two anonymous referees for useful discussions and comments on earlier drafts. Data used in this paper is available at www.nber.org/ jwolfers. The views expressed herein are those of the author(s) and do not necessarily reflect the views of the National Bureau of Economic Research.

(C2006 by Andrew Leigh and Justin Wolfers. All rights reserved. Short sections of text, not to exceed two paragraphs, may be quoted without explicit permission provided that full credit, including $@$ notice, is given to the source. 
Happiness and the Human Development Index: Australia is Not a Paradox Andrew Leigh and Justin Wolfers

NBER Working Paper No. 11925

January 2006

JEL No. I31, O57

\begin{abstract}
In "Happiness and the Human Development Index: The Paradox of Australia," Blanchflower and Oswald (2005) observe an apparent puzzle: they claim that Australia ranks highly in the Human Development Index (HDI), but relatively poorly in happiness. However, when we compare their happiness data with the HDI, Australia appears happier, not sadder, than its HDI score would predict. This conclusion also holds when we turn to a larger cross-national dataset than the one used by Blanchflower and Oswald, when we analyse life satisfaction in place of happiness, and when we measure development using GDP per capita in place of the HDI. Indeed, in the World Values Survey, only one other country (Iceland) has a significantly higher level of both life satisfaction and happiness than Australia. Our findings accord with numerous cross-national surveys conducted since the 1940s, which have consistently found that Australians report high levels of wellbeing.

Andrew Leigh

Research School of Social Sciences

Australian National University

andrew.leigh@anu.edu.au

Justin Wolfers

Business and Public Policy Department

Wharton School, University of Pennsylvania

3620 Locust Walk

Room 1456 Steinberg-Deitrich Hall

Philadelphia, PA 19104-6372

and NBER

jwolfers@wharton.upenn.edu
\end{abstract}




\section{Introduction}

Blanchflower and Oswald (2005) have recently argued that Australia presents a paradox. According to their paper, "Happiness and the Human Development Index: The Paradox of Australia”, our homeland ranks very highly in the UN Human Development Index (HDI), but her citizens are just not that happy.

We must admit that we were surprised by this conclusion: our mates are educated, intelligent, witty, and invariably good-looking. They live in cosmopolitan cities near beautiful beaches in a wonderful climate and enjoy a strong economy. Echoes of "she'll be right mate" ensure that they weather the few rough knocks that come their way with grace. So we turned to Blanchflower and Oswald's data to try to understand whether they had uncovered a hidden dark side to the Australian psyche.

Fortunately, the answer is no. When one actually compares Blanchflower and Oswald's happiness numbers with the Human Development Index, Australia is right on the regression line. Indeed, Australians are slightly happier than one might expect based on their nation's economic performance.

We also turn to alternative datasets to try to find evidence in favour of Blanchflower and Oswald's paradox, analysing data on both happiness and life satisfaction from the World Values Survey. These data suggest a robust relationship between life satisfaction and development, but also yielded no evidence of an unhappiness paradox in the case of Australia. Indeed, if anything, Australians are happier than one might expect based on her Human Development Index, or levels of GDP per capita.

Finally, we supplement Blanchflower and Oswald's analysis of happiness in Australia by considering her ranking in other surveys. In the World Values Survey, only one country has levels of both happiness and life satisfaction that are higher than Australia by a statistically significant margin. Previous international surveys from the 1940s to the 1980s, suggest a similar pattern: few countries are consistently happier than Australia.

Before proceeding, we should be clear: Our analysis does not quibble with Blanchflower and Oswald's measurement of happiness, and indeed, we base our analysis 
in the next section of the paper on their numbers. According to Blanchflower and Oswald, Australia is a paradox because she ranks $3^{\text {rd }}$ on the Human Development Index, yet in their data ranks $12^{\text {th }}$ on overall happiness, and even a bit lower on some other subindices, especially job satisfaction. Our analysis simply shows that this ordinal comparison is not particularly informative; Australia's level of development is about representative of that among industrialized nations, and her happiness is at the upper end of these countries. Taking account of small differences across industrialized countries in the HDI, and noise in the measurement of happiness, we find no evidence that Australia presents an unhappiness paradox. While Blanchflower and Oswald suggest that happiness data may provide a more appropriate welfare metric than the HDI or GDP, our analysis suggests that—at least for Australia—all three indicators yield fairly similar implications.

\section{The Paradox: The Human Development Index and Happiness}

Blanchflower and Oswald compute the mean level of happiness within the various countries represented in the 2002 round of the International Social Survey Programme (ISSP) and claim that compared to her score on the Human Development Index, Australia is unusually unhappy. ${ }^{1}$ They never actually show a cross-country comparison of the happiness and development indices, and so in Figure 1 we simply take the average happiness scores from Table 1 of their paper, chart them against the Human Development Index, and run a simple bivariate regression. ${ }^{2}$

\footnotetext{
${ }^{1}$ The Human Development Index is comprised of three equally-weighted sub-indices: a life expectancy index (based on life expectancy at birth), an education index (based on adult literacy, school enrolment, and university enrolment), and a GDP index (based on GDP per capita in US\$ at PPP).

${ }^{2}$ In the few cases where the ISSP surveys entities that are not recognised as nation-states, (eg. Northern Ireland, Great Britain, East Germany, West Germany), these are combined to form countries, so that they can be matched to the Human Development Index.
} 


\section{Figure 1}

\section{Happiness and the Human Development Index}

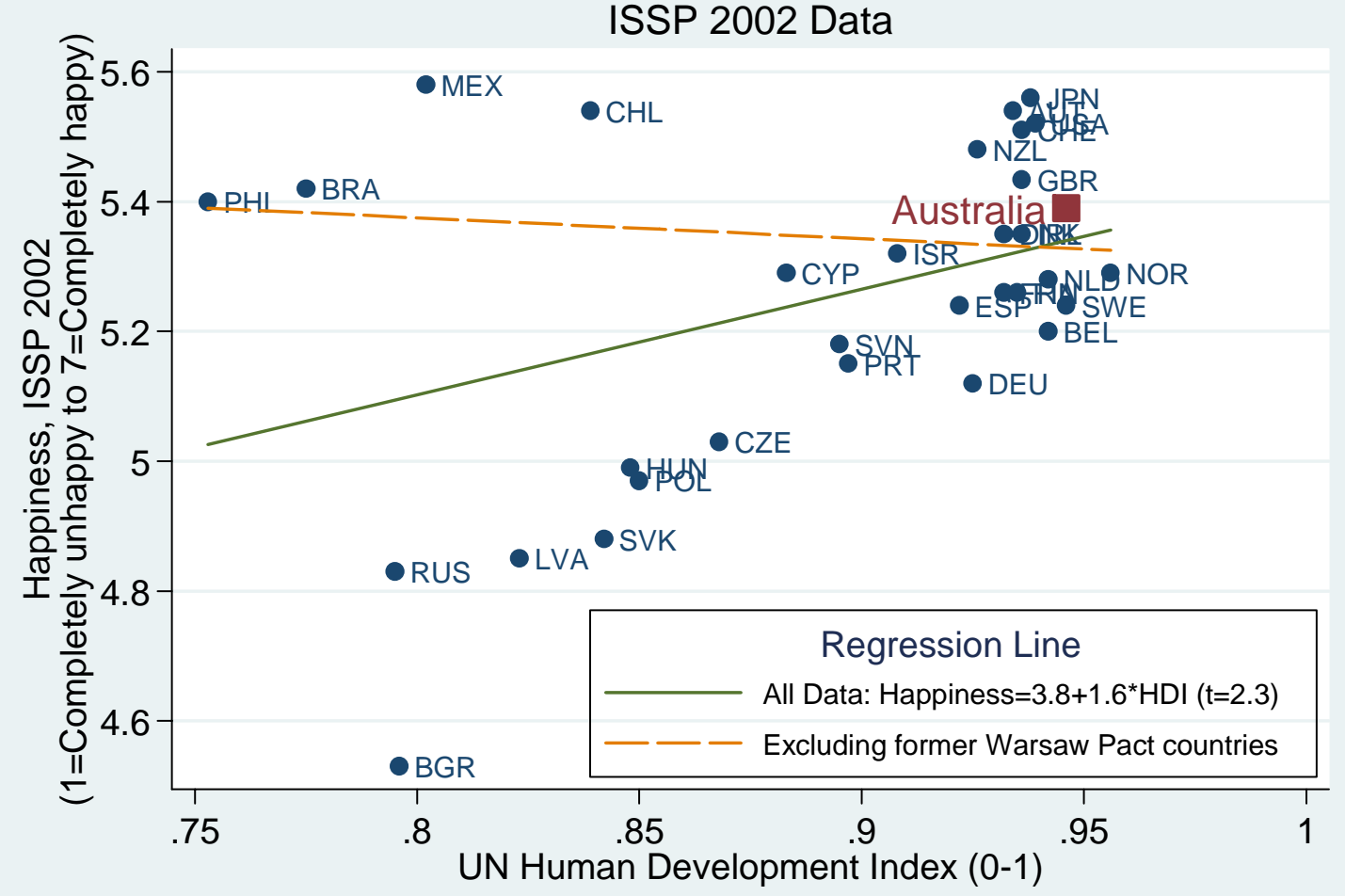

There is probably little need for formal econometrics with this chart: Australia's level of happiness looks to be entirely appropriate for a country at her level of development. The problem with Blanchflower and Oswald's inference of an Australian unhappiness paradox is that there are almost no differences in the HDI across industrialized nations. (Indeed, the 2004 Human Development Report (UNDP 2004) notes that the Human Development Index is not well suited to making fine distinctions among developed countries.) Hence Australia’s high ranking on that index does not suggest that it should be an outlier on happiness. Figure 1 suggests that the relevant comparison set is the group of other industrialized nations, and Australia is happier than most of them.

The average happiness scores in this figure are simply the average response from a 7-item qualitative response to the question: "If you were to consider your life in 
general, how happy or unhappy would you say you are, on the whole?” ${ }^{3}$ The overall pattern in this chart is qualitatively robust to alternative ways of measuring happiness, including Blanchflower and Oswald's preferred comparison, which derives from comparing country fixed-effects in an ordered logit regression, controlling for a range of individual-level controls.

While Australia is not a paradox, Figure 1 potentially does point to several paradoxes. At first glance, the Philippines, Brazil, Mexico and Chile appear unusually happy given their relatively low levels of development, and each is well above the regression line. Alternatively the former Warsaw Pact communist countries appear particularly unhappy. Omitting these countries from the regression shows that the pattern in the Eastern Bloc (Bulgaria, Russia, Latvia, Slovakia, Hungary, Poland, the Czech Republic and Slovenia) differs from the other countries. Moreover when we omit the Eastern Bloc countries, the data lead one to ask: Is there really a relationship between the Human Development Index and happiness?

To better answer this question, we now turn to a dataset on wellbeing with a much larger sample size than the ISSP, and with separate questions on happiness and life satisfaction: the World Values Survey.

\section{The World Values Survey}

There are two international social surveys that aim to cover a large fraction of the world's population: the International Social Survey Program (ISSP) analysed by Blanchflower and Oswald, and the World Values Surveys (WVS), which we now analyse. While the 2002 ISSP round covered around 50,000 individuals in 32 countries that encompass 21 percent of the world's population, the European and World Values Surveys Integrated Data File (Inglehart et al, 2005) covers 115,000 respondents in 78 countries that encompass 83 percent of the world's population. ${ }^{4}$ The WVS also includes

\footnotetext{
${ }^{3}$ The responses and their values were: "Completely happy” (7), "Very happy” (6), "Fairly happy” (5), "Neither happy nor unhappy" (4), "Fairly unhappy" (3), "Very unhappy" (2) and "Completely unhappy" (1).

${ }^{4}$ Both surveys also include some entities that are not recognized as countries by the United Nations (e.g. Northern Ireland, Puerto Rico). We drop these from our analysis.
} 
separate questions on life satisfaction and happiness. ${ }^{5}$ (Since the WVS does not contain questions on job satisfaction, our paper does not deal with Blanchflower and Oswald's findings regarding this issue.)

The main disadvantage of working with the WVS data is that the data are comprised of two separate survey waves. Of the 78 countries, 12 (including Australia) were surveyed in 1995-97, while a further 66 were surveyed in 1999-2000. Where countries were surveyed in both waves, only the later survey is included in the integrated data file. We checked other surveys, and confirmed that Australian levels of happiness and life satisfaction have been stable over the past decade. ${ }^{6}$ Comparing Australia in 199597 with other countries in 1999-2000 is therefore unlikely to bias our results.

For consistency with the previous section, we continue to compare these outcomes with the Human Development Index as measured in 2002, although given the persistence in the HDI (and wellbeing indicators), this does not much affect our findings. Following Blanchflower and Oswald, we simply use each country's mean response to the wellbeing questions.

\footnotetext{
${ }^{5}$ The WVS life satisfaction question asks: "All things considered, how satisfied are you with your life as a whole these days?" (Rankings from 1 dissatisfied to 10 satisfied). The happiness question asks: "Taking all things together, would you say you are 4 very happy, 3 quite happy, 2 not very happy, 1 not at all happy" (coding reversed from original).

${ }^{6}$ Using the linear stretch methodology of Veenhoven (2005), it is possible to compare various surveys by converting them to a 0-10 scale. For happiness, Australia's 1995 WVS score equates to 7.8 on a 0-10 scale. The three most recent happiness surveys (rescaled from 0-10) are the 2003 Australian Unity Wellbeing Index (Wave 8), which estimated mean happiness at 7.8, the 2003 Australian Survey of Social Attitudes which recorded a mean happiness level of 7.6, and the 2004-05 Roper Reports Worldwide study from GfK NOP which estimated mean happiness at 7.9. For life satisfaction, Veenhoven (2005) rescales Australia's 1995 WVS score as 7.3 on a 0-10 scale. A similar life satisfaction question (on a 0-10 scale) in the Household, Income and Labour Dynamics in Australia survey recorded a mean of 8.0 in 2001, 7.9 in 2002 and 8.0 in 2003.
} 
Figure 2

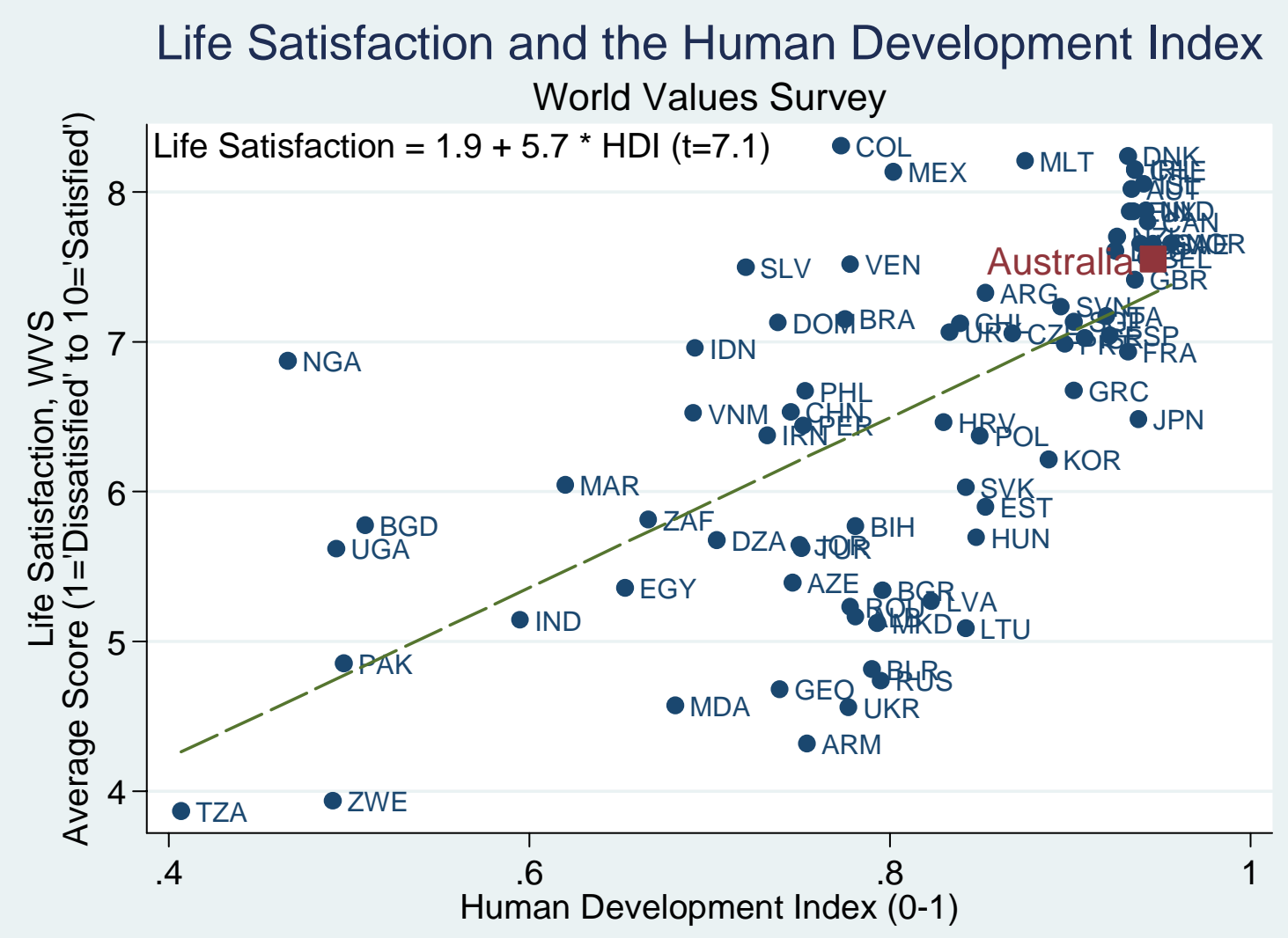

Figure 2 shows a very robust relationship between average responses to the life satisfaction question and the Human Development Index. One attractive interpretation of this regression is that it is something of a cross-validation of these two measures: both the HDI and life satisfaction scores appear to be picking up related outcomes.

However Blanchflower and Oswald analysed data on happiness rather than life satisfaction. In their analysis Blanchflower and Oswald note that "the words 'satisfaction' and 'happiness' will be used interchangeably. Whether this creates biases is not currently known." In order to assess this, Figure 3 repeats the same analysis as in Figures 1 and 2, but this time using happiness data on the broader array of countries represented in the World Values Survey. 


\section{Figure 3}

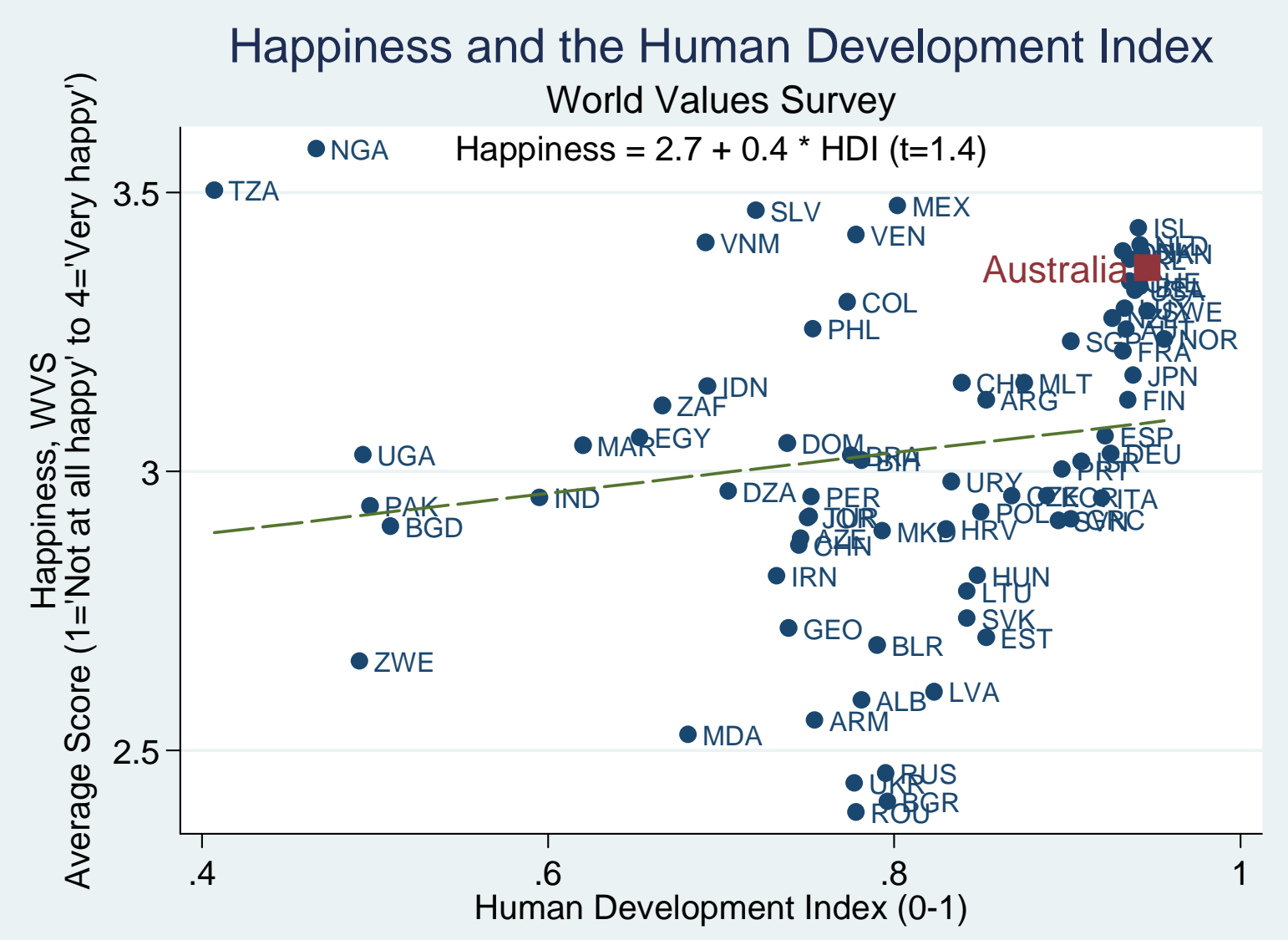

The relationship between the Human Development Index and happiness is much more tenuous, and indeed the regression line is statistically insignificant. Dropping two clear outliers, Tanzania and Nigeria, yields a statistically significant relationship. Even so, it is quite clear that the correlation between the HDI and happiness is much lower than that between the HDI and life satisfaction. Moreover, the outliers in Figure 3 are quite interesting: Nigeria ranked as the happiest country in the World Values Survey, yet was only $37^{\text {th }}$ in life satisfaction; Tanzania was second happiest, but last on life satisfaction. These outliers and the different regressions in Figures 2 and 3 suggest that there is an important distinction between happiness and life satisfaction.

As a further check on how well Australia's happiness accords with other measures of development, Figures 4 and 5 chart log GDP per capita (at purchasing power parity) against life satisfaction and happiness. (Again, we use GDP figures for 2002, though the results are similar if earlier years’ GDP are used instead.) The relationship is positive in 
both cases, though the relationship between wellbeing and GDP is much more robust for life satisfaction than for happiness. That both the HDI data and GDP per capita yield similar relationships with wellbeing is perhaps unsurprising, given that GDP makes up one-third of the HDI.

Figure 4

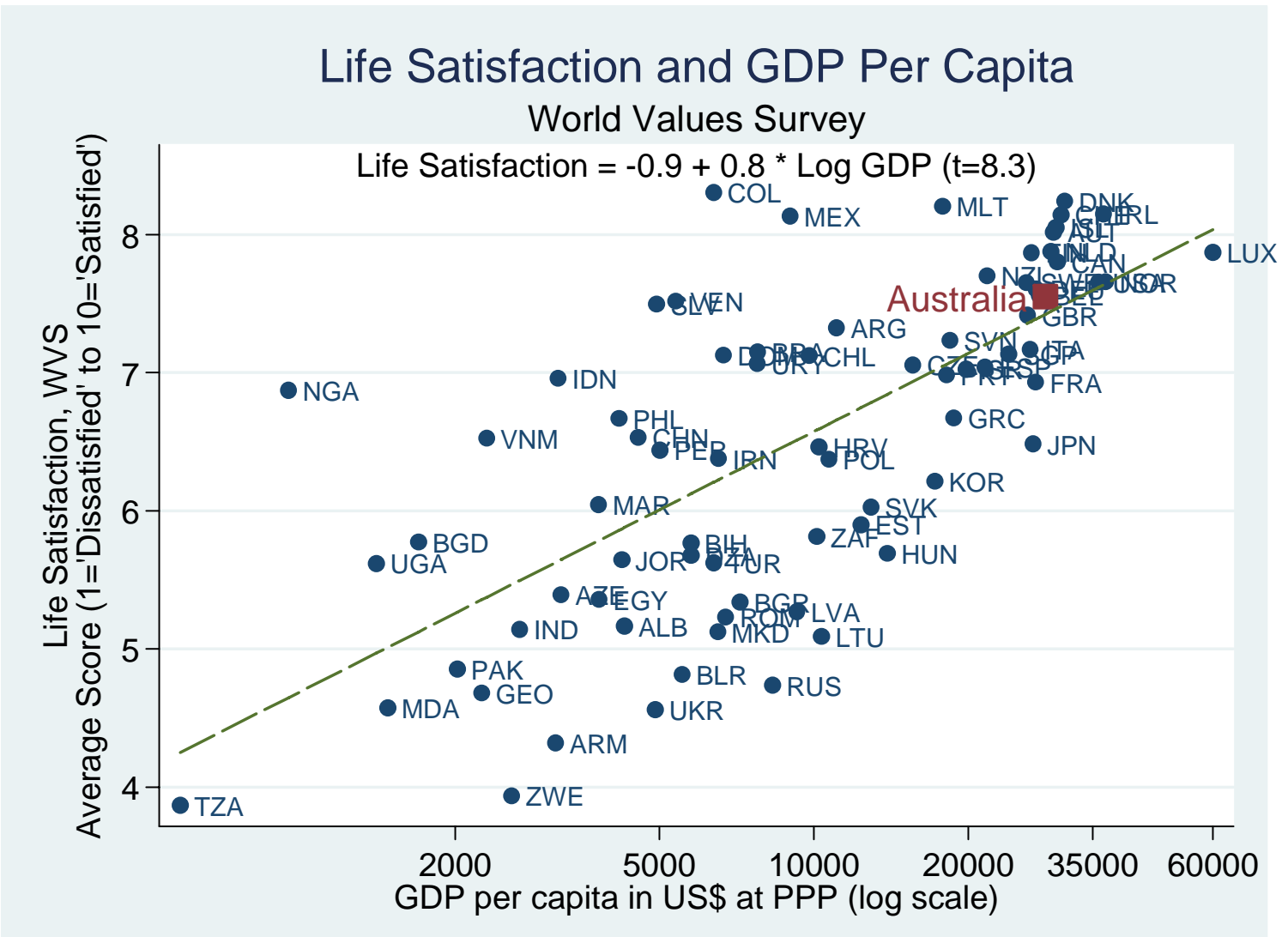




\section{Figure 5}

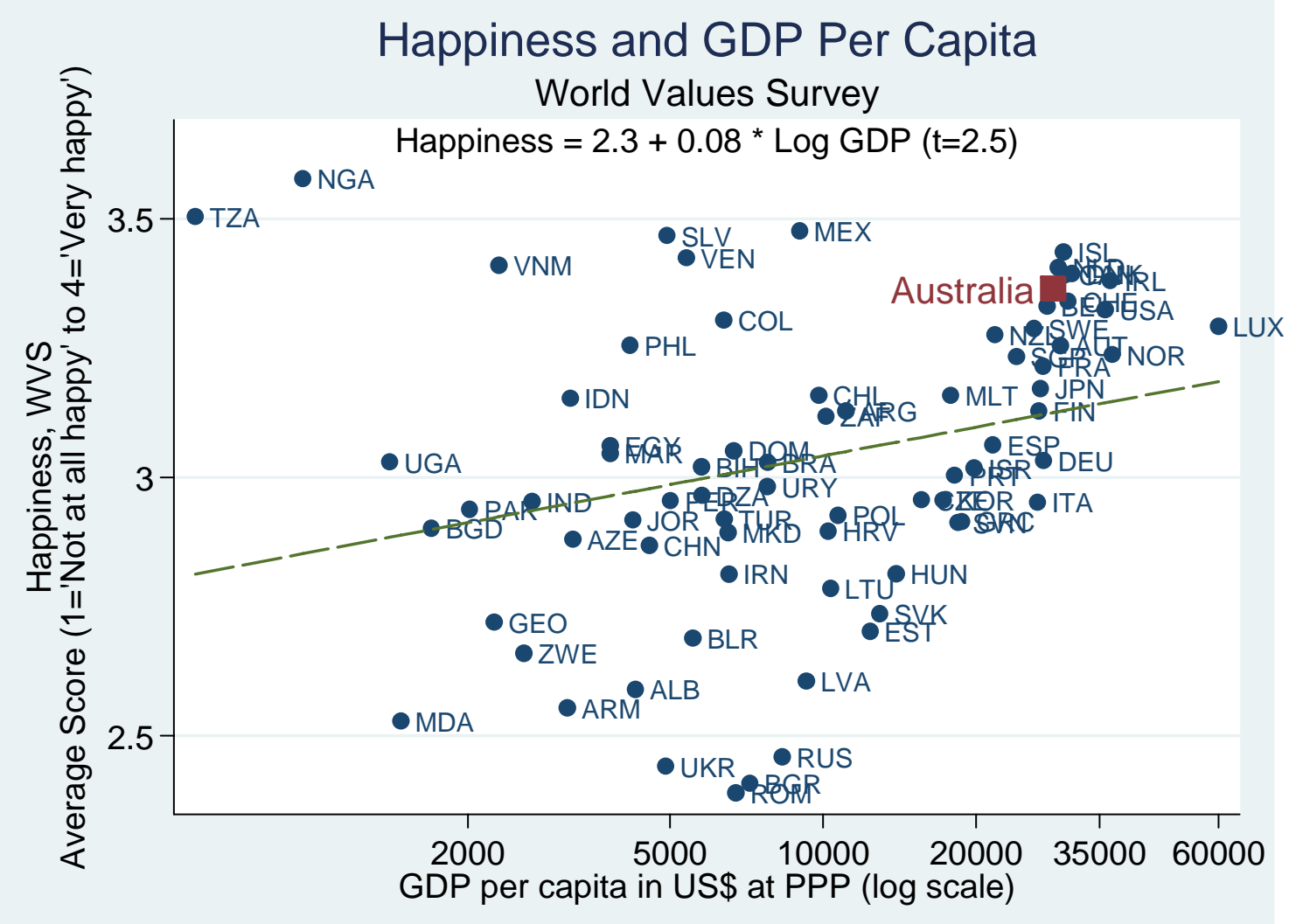

Returning to our observations on Australia, these data suggest that Australia is certainly not unhappy relative to her level of development, and if anything, her citizens are happier than might be expected, given Australia’s HDI and GDP per capita. Finally we now turn to a more fine-grained analysis of Australia's position within several crosscountry wellbeing comparisons.

\section{Australia: One of the Happiest Countries in the World?}

Given that cross-national comparisons of subjective wellbeing are quite noisy, it seems important to assess not only whether one country is happier than another, but also whether that difference is statistically significant and to check our conclusions across various datasets. As such, we ran ordered logit regressions using the microdata from the 
World Values Surveys, with country fixed effects as the only controls. (While Blanchflower and Oswald also control for demographics and marriage- and labourmarket outcomes, it is not clear to us why one would want to control for economic and social outcomes when contrasting a nation's wellbeing with her level of development. As it happens, such controls did not much affect our results, although it is plausible that a richer set of conditioning variables might have a larger impact.) 


\section{Happiness, WVS (1='Not at all happy' to 4='Very happy')}

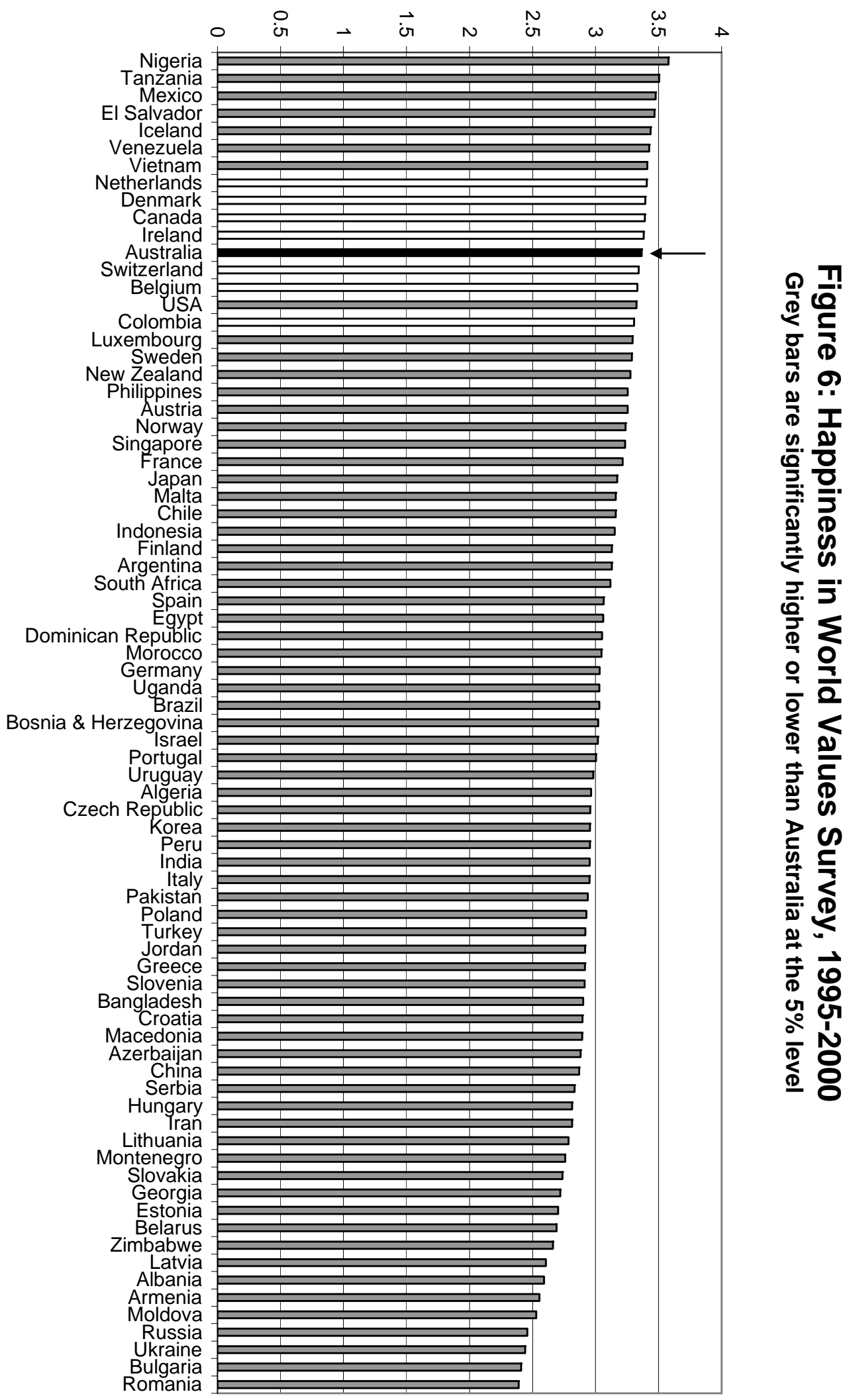


Life Satisfaction, WVS (1='Dissatisfied' to 10='Satisfied')

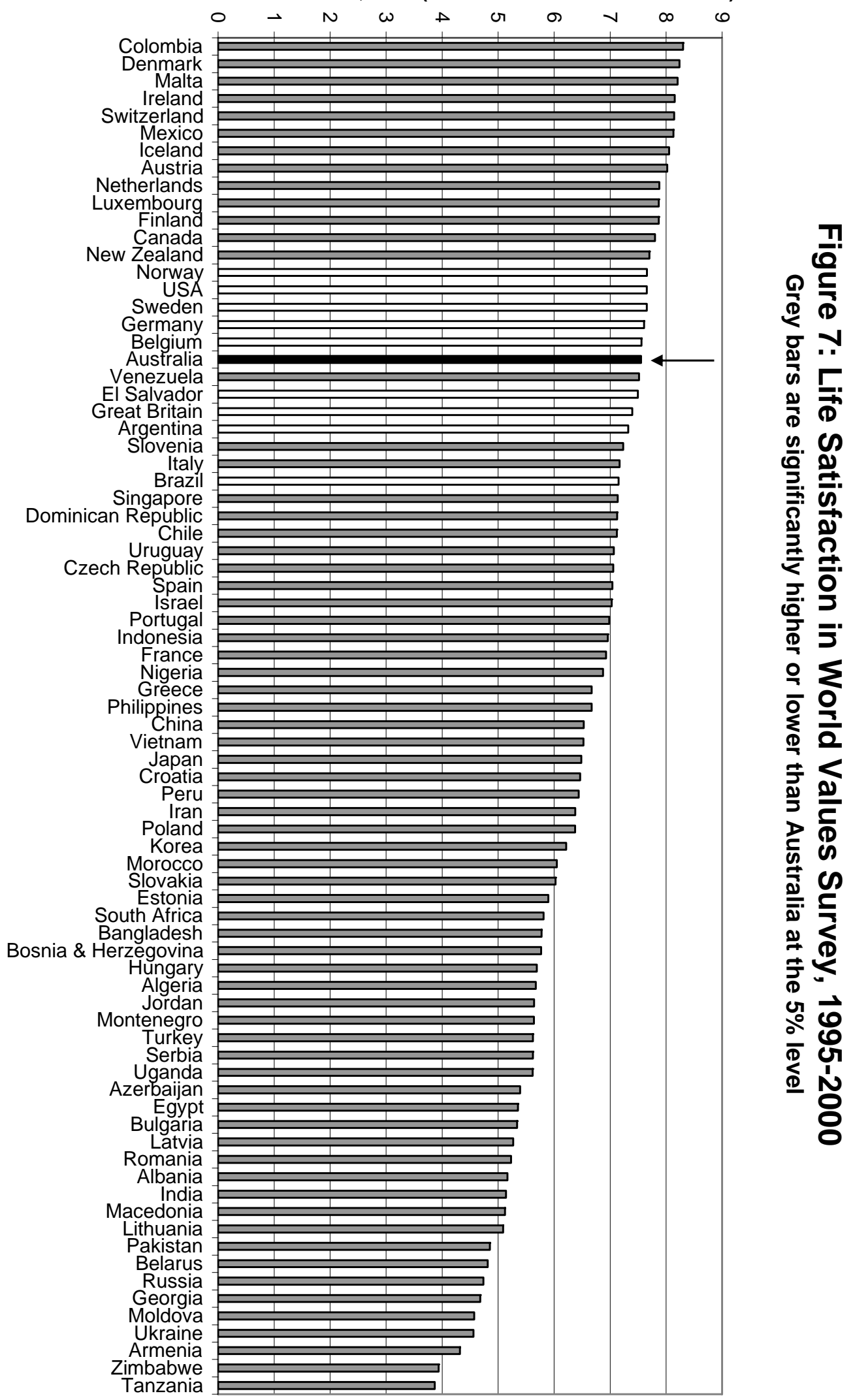


The results from these specifications are summarized in Figures 6 and 7, with Australia denoted as a black bar, countries that are not distinguishable from Australia at the 5 percent level of significance denoted with white bars, and countries that are statistically higher or lower than Australia denoted with grey bars. For happiness, the average across all countries was 3.02. In Australia, the average score was 3.36, ranking 12th out of 77 countries. For life satisfaction, the average was 6.48, with Australia scoring 7.55, and ranking 19th out of 78 countries.

The ordered logits allow us to assess which of these differences are statistically significant. In the case of happiness, only 7 countries rank ahead of Australia by a statistically significant margin: Nigeria, Tanzania, Mexico, El Salvador, Iceland, Venezuela and Vietnam. Thus in these data Iceland is the only industrialized country that is significantly happier than Australia, and no English-speaking country is significantly happier. ${ }^{7}$ Of the 65 countries with lower average happiness rankings than Australia, 62 are lower by a statistically significant margin.

In the case of life satisfaction, 13 countries have a life satisfaction ranking that exceeds Australia's by a statistically significant margin: Colombia, Denmark, Malta, Ireland, Switzerland, Mexico, Iceland, Austria, Netherlands, Luxembourg, Finland, Canada, and New Zealand. Only three of these countries are English-speaking. Fifty-nine countries have a lower life satisfaction ranking than Australia, 55 by a statistically significant margin. Overall, only Iceland outranks Australia by a statistically significant margin using both happiness and life satisfaction questions.

Indeed, Australia's relatively high levels of wellbeing have been a consistent theme since the first major cross-national happiness surveys were conducted in the 1940s (we report here only rankings within comparable studies). In the 1948 Gallup Poll, Australia ranked $1^{\text {st }}$ of 5 nations in happiness. In the 1948 Tension Study, Australia ranked $2^{\text {nd }}$ of 9 on life satisfaction. In the 1975 Kettering Survey, Australia ranked 4/12 for happiness, 1/12 for life satisfaction, and 2/12 for respondents agreeing that they were living the best possible life. In a 1979 survey conducted by the Leisure Development Center, Australia ranked 2/13 for happiness, and 3/13 for life satisfaction. In the first

\footnotetext{
${ }^{7}$ In this comparison, what matters is not the country’s official language, but whether the happiness/life satisfaction questions were translated into another language. We denote a country as English-speaking if the WVS was administered in English to more than two-thirds of respondents in that country.
} 
wave of the World Values Survey conducted over the period 1981-84, Australia ranked 5/21 for happiness, and 7/22 for life satisfaction. In the 1991 ISSP, Australia ranked 4/15 for happiness. In the 1998 ISSP, Australia ranked 6/30 for happiness. In the 2001 ISSP, Australia ranked 9/27 for happiness. In the 2002 ISSP, Australia ranked 11/32 for happiness. ${ }^{8}$ In a 2004-05 Roper Reports Worldwide study from GfK NOP (released after the publication of Blanchflower and Oswald's paper), Australia ranked 1/30 for happiness. Full results from these studies are provided in the Appendix. Throughout the period that cross-national happiness and life satisfaction surveys have been conducted, Australia has consistently ranked among the top tier of nations.

\section{Conclusion}

In two major international surveys, we find a modest positive relationship between the HDI and happiness, and a stronger positive relationship between the HDI and life satisfaction. Similar patterns are found using GDP per capita. In each case, Australia lies slightly above the regression line, indicating that Australians are a little happier (or more satisfied) than the country's ranking in the HDI (or national income per capita) would predict.

Using the WVS, the largest cross-national survey that includes questions on both happiness and life satisfaction, we found that Australia ranked 12th out of 77 countries for happiness, and 19th out of 78 for life satisfaction. Ordered logits show that some of these differences are not statistically significant. In this survey, only one country (Iceland) beat Australia by a significant margin for both happiness and life satisfaction. This should come as no surprise: across cross-national surveys conducted from the 1940s to the 1980s, Australians have consistently ranked themselves highly on measures of subjective wellbeing.

\footnotetext{
${ }^{8}$ Blanchflower and Oswald rank Australia 12th in the 2002 ISSP, since they treat Northern Ireland as a separate entity. Our analysis ranks only countries, and we therefore combine Northern Ireland with Great Britain.
} 


\section{References}

Blanchflower, David G. and Oswald, Andrew J. 2005. "Happiness and the Human Development Index: The Paradox of Australia”, Australian Economic Review 38(3): 307318

Buchanan, W. and Cantril, H. 1953. How Nations See Each Other. Urbana: University of Illinois Press

Gallup, G. H. 1976. “Human needs and satisfactions: A global survey”. Public Opinion Quarterly, 40: 459-467

Inter-university Consortium for Political and Social Research (ICPSR). 2001. International Social Survey Program: Religion II, 1998. ICPSR 3065. University of Michigan: Ann Arbor, MI

Inglehart, R et al. 2000. "World Values Surveys and European Values Surveys, 19811984, 1990-1993, and 1995-1997”, ICPSR 2790, University of Michigan: Ann Arbor, MI

Inglehart, R. et al. 2005. "European and World Values Surveys Integrated Data File, 1999-2002, Release 1”, $2^{\text {nd }}$ ICPSR version, ICPSR 3975, University of Michigan: Ann Arbor, MI

Leisure Development Center. 1980. A 13 country survey of values. Tokyo : Leisure Development Center: Lewinsohn

Nederlands Instituut voor Publieke Opinie (NIPO). 1949. "Wat de Mensen Gelukkig Maakt” (The Things that Contribute to Happiness), De Publieke Opinie 3:3-4

United Nations Development Program (UNDP). 2004. Human Development Report 2004 Cultural Liberty in Today's Diverse World. UNDP: New York, NY

Veenhoven, R. 2005. World Database of Happiness. Available at www1.eur.nl/fsw/happiness/

Zentralarchiv für Empirische Sozialforschung (ZA). 1995. International Social Survey Program 1991: Religion I. ZA Study 2150. Köln

Zentralarchiv für Empirische Sozialforschung (ZA). 2004a. International Social Survey Program 2001: Social Networks II. ZA Study 3680. Köln

Zentralarchiv für Empirische Sozialforschung (ZA). 2004b. International Social Survey Program 2002: Family and Changing Gender Roles III. ZA Study 3880. Köln 


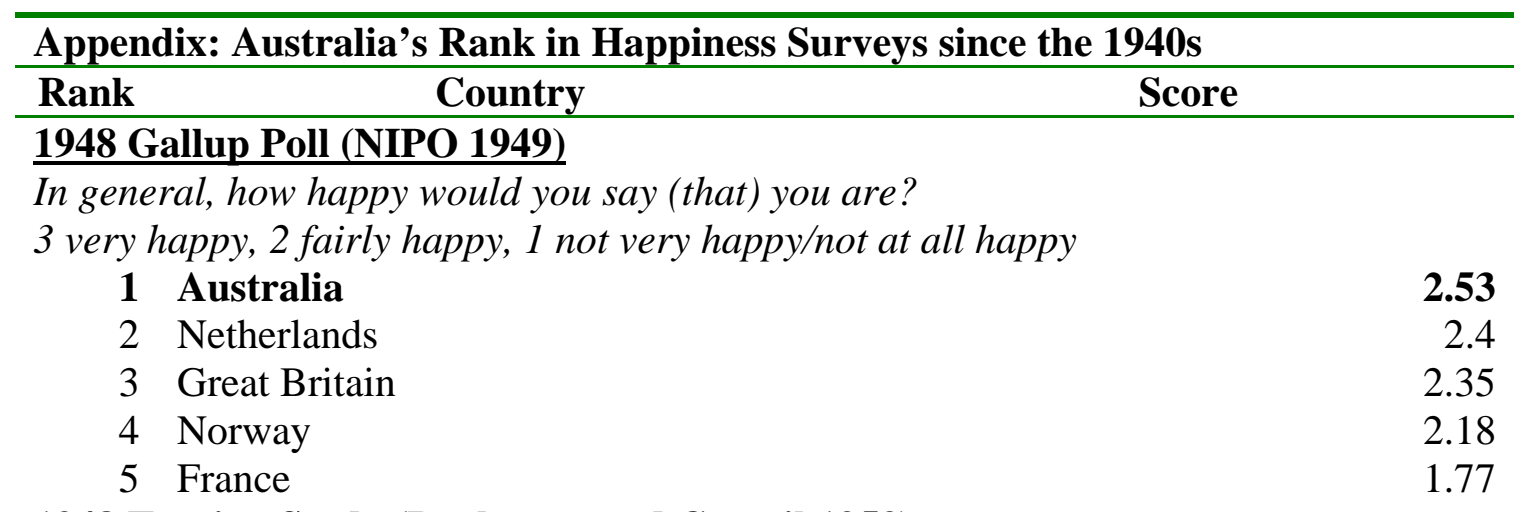

1948 Tension Study (Buchanan and Cantril 1953)

How satisfied are you with the way you are getting on now?

3 very satisfied, 2 all right, 1 not at all

$\begin{array}{lll}1 & \text { Norway } & 2.11 \\ 2 & \text { Australia } & \mathbf{2 0 2} \\ 3 & \text { U.S.A. } & 1.89 \\ 4 & \text { Great Britain } & 1.78 \\ 5 & \text { Netherlands } & 1.73 \\ 6 & \text { West Germany } & 1.57 \\ 7 & \text { Italy } & 1.57 \\ 8 & \text { Mexico } & 1.59 \\ 9 & \text { France } & 1.36\end{array}$

1975 Kettering Survey (Gallup 1976)

To indicate how you feel about your life at this time, would you use this card? Suppose the top of the mountain represents the best life you can imagine, and the bottom step of the mountain represents the worst possible life you can imagine. On which step of the mountain would you say you personally feel you stand at this time?

10 best possible life, 0 worst possible life

$\begin{array}{rlr}1 & \text { Switzerland } & 7.4 \\ 2 & \text { Australia } & 7 \\ 2 & \text { Canada } & 7 \\ 4 & \text { Great Britain } & 6.8 \\ 5 & \text { U.S.A. } & 6.68 \\ 6 & \text { West Germany } & 6.55 \\ 7 & \text { Mexico } & 6.21 \\ 8 & \text { Brazil } & 6.17 \\ 9 & \text { France } & 5.83 \\ 10 & \text { Japan } & 5.76 \\ 11 & \text { Italy } & 5.59 \\ 12 & \text { India } & 3.45\end{array}$

1975 Kettering Survey (Gallup 1976)

Generally speaking, how happy would you say you are?

3 very happy, 2 fairly happy, 1 not too happy

1 Canada 2.32

2 (eq) Great Britain $\quad 2.31$ 


\begin{tabular}{rlc}
\hline \multicolumn{3}{l}{ Appendix: Australia's Rank in Happiness Surveys since the 1940s } \\
\hline Rank & \multicolumn{3}{c}{ Country } & Score \\
\hline 2 (eq) & U.S.A. & \\
$\mathbf{4}$ & Australia & 2.31 \\
5 & Brazil & 2.31 \\
6 & Switzerland & 2.18 \\
7 & France & 2.17 \\
8 & West Germany & 2.12 \\
9 & Mexico & 1.92 \\
10 & Japan & 1.89 \\
11 & Italy & 1.84 \\
12 & India & 1.78 \\
\end{tabular}

1975 Kettering Survey (Gallup 1976)

Now taking everything about your life into account, how satisfied or dissatisfied are you with your life today?

10 satisfied, 0 dissatisfied

$\begin{array}{rlr}\mathbf{1} & \text { Australia } & \mathbf{7 . 9 1} \\ 2 & \text { Canada } & 7.7 \\ 3 & \text { U.S.A. } & 7.63 \\ 4 & \text { Great Britain } & 7.51 \\ 5 & \text { West Germany } & 7.3 \\ 6 & \text { Brazil } & 7.03 \\ 7 & \text { Mexico } & 6.97 \\ 8 & \text { France } & 6.63 \\ 9 & \text { Italy } & 6.33 \\ 10 & \text { Japan } & 6.05 \\ 11 & \text { India } & 3.45\end{array}$

1979 Survey (Leisure Development Center 1980)

How happy do you feel as you live now? Please choose one item on this card that comes closest to your feeling.

5 very happy, 4 fairly happy, 3 neither happy nor unhappy, 2 fairly unhappy, 1 very unhappy

1 Great Britain

2 Australia

4.33

3 U.S.A.

4.28

4 Canada

4.22

5 Brazil

4.14

5 Singapore

4.21

7 Philippines

3.78

8 France

3.78

9 West Germany

3.72

10 Japan

3.68

11 India

3.67

12 Italy

3.66

13 South Korea 


\begin{tabular}{|c|c|c|}
\hline \multicolumn{3}{|c|}{ Appendix: Australia's Rank in Happiness Surveys since the 1940s } \\
\hline Rank & Country & Score \\
\hline \multicolumn{3}{|c|}{1979 Survey (Leisure Development Center 1980) } \\
\hline \multicolumn{3}{|c|}{ Overall, how satisfied are you with your present life? } \\
\hline \multicolumn{3}{|c|}{$\begin{array}{l}5 \text { very satisfied, } 4 \text { fairly satisfied, } 3 \text { neither satisfied nor dissatisfied, } 2 \text { fairly } \\
\text { dissatisfied, } 1 \text { very dissatisfied }\end{array}$} \\
\hline 1 & Great Britain & 4.28 \\
\hline 2 & U.S.A. & 4.2 \\
\hline 3 & Australia & 4.19 \\
\hline 4 & Canada & 4.18 \\
\hline 5 & Singapore & 4.17 \\
\hline 6 & Brazil & 4.02 \\
\hline 7 & Philippines & 3.9 \\
\hline 8 & West Germany & 3.89 \\
\hline 9 & Italy & 3.84 \\
\hline 10 & France & 3.76 \\
\hline 11 & India & 3.69 \\
\hline 12 & Japan & 3.45 \\
\hline 13 & South Korea & 3.27 \\
\hline \multicolumn{3}{|c|}{ 1981-84 World Values Survey (Inglehart 2000) } \\
\hline \multicolumn{3}{|c|}{$\begin{array}{l}\text { All things considered, how satisfied are you with your life as a whole now? } \\
1 \text { dissatisfied, } 10 \text { satisfied }\end{array}$} \\
\hline 1 & Denmark & 8.19 \\
\hline 2 & Iceland & 8.09 \\
\hline 3 & Sweden & 8.01 \\
\hline 4 & Mexico & 7.97 \\
\hline 5 & Finland & 7.91 \\
\hline 6 & Norway & 7.90 \\
\hline 7 & Australia & 7.88 \\
\hline 8 & Canada & 7.85 \\
\hline 9 & U.S.A. & 7.73 \\
\hline 10 & Ireland & 7.71 \\
\hline 11 & Netherlands & 7.69 \\
\hline 12 & Britain & 7.65 \\
\hline 13 & Belgium & 7.39 \\
\hline & West Germany & 7.17 \\
\hline 15 & Hungary & 6.93 \\
\hline & Argentina & 6.79 \\
\hline 17 & France & 6.70 \\
\hline 18 & Italy & 6.69 \\
\hline 19 & Spain & 6.60 \\
\hline 20 & Japan & 6.59 \\
\hline & South Africa & 6.30 \\
\hline 22 & South Korea & 5.33 \\
\hline
\end{tabular}




\begin{tabular}{|c|c|c|}
\hline \multicolumn{3}{|c|}{ Appendix: Australia's Rank in Happiness Surveys since the 1940s } \\
\hline Rank & & Score \\
\hline \multicolumn{3}{|c|}{ 1981-84 World Values Survey (Inglehart 2000) } \\
\hline \multicolumn{3}{|c|}{ Taking all things together, would you say you are } \\
\hline \multicolumn{3}{|c|}{4 very happy, 3 quite happy, 2 not very happy, 1 not at all happy } \\
\hline 1 & Iceland & 3.40 \\
\hline 2 & Ireland & 3.36 \\
\hline 3 & Britain & 3.34 \\
\hline 4 & Canada & 3.31 \\
\hline 5 & Australia & 3.30 \\
\hline 6 & Netherlands & 3.30 \\
\hline 7 & Belgium & 3.28 \\
\hline 8 & Denmark & 3.25 \\
\hline 9 & Sweden & 3.24 \\
\hline 10 & U.S.A. & 3.24 \\
\hline 11 & Norway & 3.21 \\
\hline 12 & Mexico & 3.14 \\
\hline 13 & France & 3.11 \\
\hline 14 & Finland & 3.10 \\
\hline 15 & Japan & 2.98 \\
\hline 16 & Spain & 2.98 \\
\hline 17 & West Germany & 2.96 \\
\hline 18 & Argentina & 2.95 \\
\hline 19 & South Africa & 2.91 \\
\hline 20 & Italy & 2.86 \\
\hline 21 & Hungary & 2.85 \\
\hline
\end{tabular}

1991 International Social Survey Program (ZA 1995)

If you were to consider your life as a whole these days, how happy or unhappy would you say you are, on the whole?

4 very happy, 3 fairly happy, 2 not very happy, 1 not at all happy

1 Ireland

2 USA

3 Great Britain

4 Australia

5 Netherlands

6 Austria

3.18

7 New Zealand

3.18

8 Norway

3.09

9 Philippines

3.07

10 Germany

2.99

11 Israel

2.88

12 Poland

2.80

13 Russia

2.71

14 Hungary

2.64

15 Slovenia

2.58 


\begin{tabular}{lcl}
\hline Appendix: Australia's Rank in Happiness Surveys since the 1940s \\
\hline Rank & Country & Score \\
\hline
\end{tabular}

1998 International Social Survey Program (ICPSR 2001)

If you were to consider your life as a whole these days, how happy or unhappy would you say you are, on the whole?

4 very happy, 3 fairly happy, 2 not very happy, 1 not at all happy

1 Ireland

2 New Zealand

3 Netherlands

3.24

4 Great Britain

3.24

5 USA

3.24

6 Australia

3.22

7 Denmark

3.19

8 Switzerland

3.18

9 Austria

3.12

10 Norway

3.10

11 Sweden

3.08

12 Canada

3.06

13 Philippines

3.05

14 Spain

3.05

15 Japan

3.01

16 Poland

2.98

17 Israel

2.92

18 Germany

2.91

19 France

2.90

20 Cyprus

2.89

21 Czech Republic

22 Italy

2.87

23 Chile

2.82

24 Slovenia

2.74

25 Portugal

2.69

26 Slovakia

2.64

27 Russia

2.50

28 Latvia

2.47

29 Bulgaria

2.45

30 Hungary

2.44

\section{International Social Survey Program (ZA 2004a)}

If you were to consider your life in general these days, how happy or unhappy would you say you are, on the whole?

4 very happy, 3 fairly happy, 2 not very happy, 1 not at all happy

\begin{tabular}{lll}
1 & Brazil & 3.45 \\
2 & Switzerland & 3.33 \\
3 & United States & 3.32 \\
4 & New Zealand & 3.31 \\
5 & Canada & 3.27 \\
6 & Great Britain & 3.24 \\
\hline
\end{tabular}




\begin{tabular}{rlr}
\hline \multicolumn{3}{c}{ Appendix: Australia's Rank in Happiness Surveys since the 1940s } \\
\hline Rank & \multicolumn{1}{c}{ Country } & Score \\
\hline 7 & Austria & 3.21 \\
8 & Chile & 3.20 \\
9 & Australia & 3.17 \\
10 & Denmark & 3.16 \\
11 & France & 3.16 \\
12 & Japan & 3.13 \\
13 & Norway & 3.10 \\
14 & Philippines & 3.10 \\
15 & Germany & 3.04 \\
16 & Spain & 3.00 \\
17 & Finland & 2.96 \\
18 & Czech Republic & 2.89 \\
19 & South Africa & 2.88 \\
20 & Slovenia & 2.88 \\
21 & Poland & 2.87 \\
22 & Israel & 2.86 \\
23 & Italy & 2.82 \\
24 & Hungary & 2.81 \\
25 & Cyprus & 2.73 \\
26 & Latvia & 2.56 \\
27 & Russia & 2.06
\end{tabular}

2002 International Social Survey Program (ZA 2004b)

If you were to consider your life in general, how happy or unhappy would you say you are, on the whole?

7 completely happy, 6 very happy, 5 fairly happy, 4 neither happy nor unhappy, 3 fairly unhappy, 2 very unhappy, 1 completely unhappy

1 Mexico

5.58

2 Japan

5.56

3 Austria

5.54

4 Chile

5.54

5 United States

5.52

6 Switzerland

5.51

7 New Zealand

5.48

8 United Kingdom

5.43

9 Brazil

5.42

10 Philippines

5.40

11 Australia

5.39

12 Denmark

5.35

13 Ireland

5.35

14 Israel

5.32

15 Cyprus

5.29

16 Norway

5.29

17 Netherlands

5.28

18 Finland

5.26 


\begin{tabular}{rlr}
\hline \multicolumn{3}{l}{ Appendix: Australia's Rank in Happiness Surveys since the 1940s } \\
\hline Rank & \multicolumn{1}{c}{ Country } & Score \\
\hline 19 & France & 5.26 \\
20 & Spain & 5.24 \\
21 & Sweden & 5.24 \\
22 & Belgium & 5.20 \\
23 & Slovenia & 5.18 \\
24 & Portugal & 5.15 \\
25 & Germany & 5.12 \\
26 & Czech Republic & 5.03 \\
27 & Hungary & 4.99 \\
28 & Poland & 4.97 \\
29 & Slovakia & 4.88 \\
30 & Latvia & 4.85 \\
31 & Russia & 4.83 \\
32 & Bulgaria & 4.53 \\
$\mathbf{2 0 0 4 - 0 5}$ Roper Reports Worldwide study from GfK NOP & \\
\hline How happy would you say you are with the overall quality of your life? & \\
4 very happy, 3 satisfied, 2 disappointed, 1 very unhappy & \\
$\mathbf{1}$ & Australia & 3.37 \\
2 & India & 3.34 \\
3 & USA & 3.28 \\
4 & Egypt & 3.24 \\
5 & Thailand & 3.24 \\
6 & Canada & 3.24 \\
7 & U.K. & 3.23 \\
8 & Sweden & 3.22 \\
9 & Saudi Arabia & 3.21 \\
10 & Mexico & 3.21 \\
11 & Brazil & 3.11 \\
12 & Venezuela & 3.10 \\
13 & Indonesia & 3.09 \\
14 & Argentina & 3.05 \\
15 & Philippines & 3.05 \\
16 & China & 2.93 \\
17 & Italy & 2.90 \\
18 & Spain & 2.89 \\
19 & Czech Republic & 2.88 \\
20 & South Africa & 2.88 \\
21 & France & 2.88 \\
22 & Hong Kong & 2.85 \\
23 & Poland & 2.83 \\
24 & Germany & 2.82 \\
25 & Hungary & 2.80 \\
26 & Turkey & 2.79 \\
27 & Korea & 2.77 \\
\hline & & \\
\hline
\end{tabular}




\begin{tabular}{|c|c|c|c|}
\hline \multicolumn{4}{|c|}{ Appendix: Australia's Rank in Happiness Surveys since the 1940s } \\
\hline Rank & Country & Score & \\
\hline 28 & & & 2.68 \\
\hline 29 & & & 2.63 \\
\hline 30 & & & 2.63 \\
\hline
\end{tabular}

Notes:

1. Figures from 1948-1979 are drawn from the World Database of Happiness (Veenhoven 2005). Figures for 1981-98 were calculated by the authors, using weighted microdata from the WVS, and unweighted tabulations from the ISSP codebooks.

2. In all cases, we exclude observations that cover multiple-country regions (eg. Latin America), or part of a country (eg. Northern Ireland). For 1991, 1998, 2001 and 2002, East and West Germany are combined in proportion to their population shares. In the 2001 ISSP, Israel (Jews) and Israel (Arabs) are combined in proportion to their population shares.

3. Where the original survey coded lower numbers as denoting higher levels of happiness, coding is reversed.

4. The 1991 ISSP codebook notes that the wording of the happiness question differs slightly for Russia.

5. In the 2004-05 Roper Reports Worldwide study, the response "No real feelings" is coded as missing. 